\title{
Rehabilitation of Degraded Tropical Rainforest Using Dipterocarp Trees in Sarawak, Malaysia
}

\author{
Hattori Daisuke, ${ }^{1,2}$ Kenzo Tanaka, ${ }^{3}$ Kendawang Joseph Jawa, \\ Ninomiya Ikuo, ${ }^{5}$ and Sakurai Katsutoshi ${ }^{6}$ \\ ${ }^{1}$ United Graduate School of Agricultural Sciences, Ehime University, Matsuyama 790-8566, Japan \\ ${ }^{2}$ Tokushima Center for Climate Change Actions, 1-23 Higashiokinosu, Tokushima 770-0873, Japan \\ ${ }^{3}$ Forestry and Forest Products Research Institute, Tsukuba 305-8687, Japan \\ ${ }^{4}$ Forest Department Sarawak, 8th Floor, Wisma Sumber Alam, Jalan Stadium, Petra Jaya, 93660 Kuching, Sarawak, Malaysia \\ ${ }^{5}$ Faculty of Agriculture, Ehime University, Matsuyama, Ehime 790-8566, Japan \\ ${ }^{6}$ Faculty of Agriculture, Kochi University, Nankoku 783-8502, Japan
}

Correspondence should be addressed to Hattori Daisuke; ecomirai.hattori@gmail.com

Received 23 March 2013; Revised 28 July 2013; Accepted 16 August 2013

Academic Editor: Brian C. McCarthy

Copyright (C) 2013 Hattori Daisuke et al. This is an open access article distributed under the Creative Commons Attribution License, which permits unrestricted use, distribution, and reproduction in any medium, provided the original work is properly cited.

To develop rehabilitation planting techniques in tropical degraded forests, we investigated (1) basic soil characteristics and light conditions; (2) growth and survival of seven dipterocarp seedlings over 81 months; and (3) the effect of environmental factors on the survival of seedlings grown in three degraded vegetations (grassland, secondary forest, and logged forest) in Sarawak, Malaysia. The soil was weakly acidic, and kaolin minerals dominated. The amount of exchangeable bases in surface soils, soil temperature $\left(>35^{\circ} \mathrm{C}\right)$, and relative light intensity were all highest in the grassland. Seedling growth was also highest in the grassland, whereas many seedlings died there over 81 months. Growth and survivability were very similar in secondary and logged forests. The death of the seedlings in the grassland was attributable to an extremely high light intensity for all species. In contrast, the seedling growth rate in all species was also enhanced by light intensity. In conclusion, dipterocarp seedlings can be planted on highly degraded land such as grassland, although high light intensity limits their survival. Planting under nurse trees such as regenerated pioneer trees may be an effective method to enhance seedling survival under open conditions such as grassland.

\section{Introduction}

Anthropogenic activities such as timber extraction, shifting cultivation, and the establishment of commercial plantations have led to the conversion, fragmentation, and degradation of tropical rain forests [1-3]. Various types of degraded forests remain after such degradation because of differences in the type of disturbance, environmental conditions, time elapsed since the disturbance, and the original vegetation type. These degraded forests can be broadly divided into three types of degraded vegetation, namely, grassland after burning, early successional secondary forest, and logged over forest after commercial logging [4]. The provision of ecosystem services, including carbon storage, timber and food provision, freshwater management, and soil protection, on these degraded lands is poor compared with nondegraded forests
[5]. The rehabilitation of degraded tropical forest ecosystems is therefore a major issue in both regional and global context $[6,7]$. Planting of indigenous trees is considered to be an effective rehabilitation method for such degraded tropical rain forests, because these trees provide benefits such as timber, food, and medical products [8-13].

Environmental characteristics such as microclimate, soil qualities, and light conditions play essential roles in the ecosystems of tropical rain forests [14-18] and are also important for the performance of planted seedlings in the field $[4,19,20]$. However, deforestation can lead to the deterioration of environmental conditions by generating high light intensity and severe soil mineral erosion. Moreover, these characteristics may vary substantially among different degraded vegetation types. Therefore, an understanding of the effects of environmental factors on seedlings planted in 
each degraded vegetation type is required for the development of suitable rehabilitation planting techniques in tropical rain forests.

In tropical Southeast Asia, dipterocarps are the most dominant forest species. They vary from moderately to highly shade-tolerant when they are saplings [21-23]. Several researchers have proposed planting methods that use nurse trees to raise dipterocarp seedlings [24-26]. Similarly, the planting of seedlings under secondary forest cover has been recommended for dipterocarp regeneration [27], because secondary forest trees may provide optimal shade conditions for the growth of dipterocarp seedlings [12, 26, 28]. However, few studies have investigated the performance of dipterocarp trees seedlings planted in different types of degraded local habitats, ascertaining which habitat provides suitable conditions for the seedlings $[4,12]$.

To develop proper rehabilitation techniques for the degraded mixed dipterocarp forest ecosystems, an experimental rehabilitation scheme was undertaken at Niah Forest Reserve, Sarawak, Malaysia, from 2000 [29]. At the site, seedlings of dipterocarps and other indigenous tree species (20 species, 26,316 individuals) were planted under different degraded forest vegetation types. In this study, we investigated (1) soil properties, soil temperature, and relative light intensity (RLI); (2) the survivability and growth of seven dipterocarp seedlings over 81 months; and (3) the effects of surface soil properties and light conditions on the survival and growth of dipterocarp seedlings under the three degraded vegetations (treatments are grassland, secondary forest, and logged forest). The overall aim was to further develop forest rehabilitation techniques, including enrichment planting for the tropical rain forests of Southeast Asia.

\section{Materials and Methods}

2.1. Study Plot and Seedlings. The study site was located in the Niah Forest Reserve in Sarawak, Malaysia $\left(3^{\circ} 39^{\prime} \mathrm{N}, 113^{\circ} 42^{\prime} \mathrm{E}\right)$. This area is classified as humid tropics [31] with an average annual air temperature of $27^{\circ} \mathrm{C}$ and an annual rainfall of $2,800 \mathrm{~mm}$. The site was located in the lowland rain forest between 40 and 50 masl. The slope was gentle to moderate with a gradient of less than $25^{\circ}$ [32]. Baillie [33] previously described an area in the Niah Forest Reserve adjoining the study site that was comprised mainly of moderately soft grey mudstones and shales. The soil was classified as Ultisol [34]. Detailed soil information was shown in a previous paper [33].

The original vegetation was a mixed dipterocarp forest, and the three current types of vegetation developed as a result of forest degradation, namely, grassland, secondary forest, and logged forest. The grassland resulted from shifting cultivation practices in 1999, one year after cultivation had ended. The grassland was dominated by grasses, ferns, and saplings of pioneer trees. Ground coverage was estimated about $70 \%$ for grasses such as Eupatorium odoratum, Scleria bancana, and Panicum sp, about $10-20 \%$ for ferns such as Blechnum orientale and Nephrolepis biserrata, and 10-20\% for pioneer trees such as Alphitonia excelsa, Trema orientalis, and Macaranga sp., respectively. Secondary forest developed where land had been used for cultivation after that ended in the 1980s. The genus Macaranga (Euphorbiaceae), one of the typical pioneer trees in Southeast Asia, dominated the site at $20 \mathrm{~m}$ in height. The logged forest was a mixed dipterocarp forest which has been lightly logged at least once in 1980s. Our plots in the logged forest were the most similar to their original species composition, though tree sizes were smaller than those of the original forest.

To develop and establish a rehabilitation strategy for the degraded mixed dipterocarp forest ecosystems, an experimental scheme was carried out at the study site established in the Niah Forest Reserve, Sarawak, in 2000. At the site, seedlings of dipterocarps and other indigenous tree species (20 species, 26,316 individuals) were planted by "island and corridor" methods under degraded forest vegetation beginning in 2000 [29]. Thirty-six seedlings of each species were planted in a $14 \times 14 \mathrm{~m}$ square, referred to as an "island," at $2 \times 2 \mathrm{~m}$ spacing intervals. Meanwhile, in the rectangular "corridor" measuring $3 \times 36 \mathrm{~m}$, four seedlings (single species) were planted closely, and seven gatherings were distributed at intervals of $5 \mathrm{~m}$ (totally 28 seedlings) (Figure 1). We did not plant seedlings in the outer perimeter of the island so as to provide a buffer zone. Seeds were collected in forests around Niah Forest Reserve during a mass flowering event from 1998 to 1999 and germinated in black plastic bags filled with forest subsoil. Seedlings were raised in a nursery under a neutraldensity shade netting ( $40 \%$ full sun) for one year. Two weeks prior to planting, the shade net was removed to harden the seedlings, which were transplanted to the study site in MayJune 2000. Climbers were removed from planted seedlings as they developed, and grasses, herbs, ferns, and small trees with diameters $<5 \mathrm{~cm}$ were removed from the plot area [30].

Within each of the three treatments, seven "islands" (totally 21 islands) with seven dipterocarp species (totally 756 seedlings) were selected as a research plot. The species of the selected seedlings were Dryobalanops beccarii Dyer, Parashorea macrophylla Wyatt-Sm. ex P. S. Ashton, Shorea macrophylla (de Vriese) P. S. Ashton, S. ovata Dyer ex Brandis, S. parvifolia Dyer, S. seminis v. Slooten, and S. virescens Parijs. All selected species are high grade timber trees, and seeds of Shorea macrophylla and S. seminis provide edible oil as illipe nut [21]. The number of survived seedlings, height, and diameter was measured at $0,3,6,9,12,24,36,50,62$, and 81 months after planting (2000-2007) (Table 5). The total biomass of the seedlings in the research plots was calculated using an allometric equation including belowground biomass, and the formulas are as follows; Dryobalanops beccarii: $Y=1.50 X^{0.760}$, Parashorea macrophylla: $Y=0.77 X^{0.86}$, Shorea macrophylla: $Y$ $=0.33 X^{0.99}$, S. ovata: $Y=0.43 X^{0.98}$, S. parvifolia: $Y=0.33 X^{0.99}$, S. seminis: $Y=0.47 X^{0.92}$, and $S$. virescens: $Y=1.13 X^{0.79}$, $\left(Y(\mathrm{~g})=\right.$ biomass, $X\left(\mathrm{~cm}^{3}\right)=$ diameter $^{2} \times$ height $)[35]$.

2.2. Measurement of Light and Soil Properties. At the planting in 2000, six soil profiles were surveyed, and soil samples were collected at eight depths, from 0 to $105 \mathrm{~cm}$, to determine basic soil characteristics. Surface soils $(0-5 \mathrm{~cm})$ taken from the experimental plots ( 21 plots) were analysed for general 


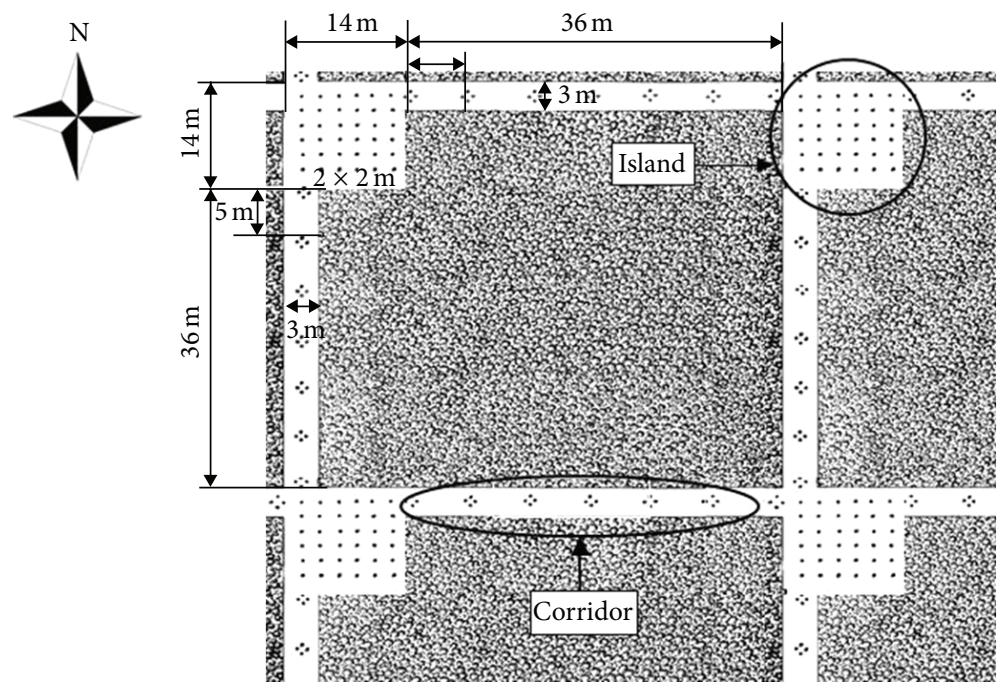

FIGURE 1: "Island and corridor" planting method (after Hattori et al. 2009 [30]).

soil physicochemical properties in 2002. Soil hardness was measured in 2000 with a Hasegawa-type cone penetrometer (Daito Techno Green Co., Tokyo, H-60) from the soil surface to a depth of $60 \mathrm{~cm}$, using eight replicates per plot. Soil temperature was recorded with a thermometer (GSI Creos Co., Tokyo, Tomprobe) at 5 and $25 \mathrm{~cm}$ depths in a representative location of each vegetation plot in 2003. The RLI was measured in 2002 using a relative illumination meter (Konica Minolta Co., Tokyo, Digital Illumination Meter T$1 \mathrm{H})$ at an aboveground height of $130 \mathrm{~cm}$ on a cloudy day with 30 replicates for each plot.

Soil samples were air-dried and passed through a $2 \mathrm{~mm}$ mesh sieve. Laboratory experiments were conducted in Kochi University, Japan. Soil electric conductivity (EC) was measured in an $\mathrm{H}_{2} \mathrm{O}$ solution (soil to solute ratio of $1: 5$ ) using an EC meter. Soil pH was measured in an $\mathrm{H}_{2} \mathrm{O}$ solution (soil to solute ratio of 1:5) using the glass electrode method. Total carbon (T-C) content was determined with an NC Analyzer (Sumika Chemical Analysis Service Co., Tokyo, Sumigraph model NC-80). Exchangeable Al was extracted with $1 \mathrm{M} \mathrm{KCl}$, and the concentration was measured by titration. Cation exchange capacity (CEC) and the amounts of exchangeable bases $(\mathrm{Ca}, \mathrm{Mg}, \mathrm{K}$, and $\mathrm{Na}$ ) were measured after successive extraction using $1 \mathrm{M} \mathrm{NH}_{4}-\mathrm{OAc}(\mathrm{pH} 7.0$ ) and $10 \% \mathrm{NaCl}$. The amount of $\mathrm{NH}_{4}^{+}$replaced by Na was determined using the steam-distillation method. Exchangeable base concentrations were determined by atomic absorption spectrometry (Ca, $\mathrm{Mg}$, and $\mathrm{K}$ ) and flame photometry (Na) (Shimadzu Co., Kyoto, AA-610S). Soluble $\mathrm{Al}$ and $\mathrm{Fe}$ in ammonium oxalate (Alo and Feo) were extracted by the methods reported in Mckeague and Day [36]. Soluble $\mathrm{Al}$ and $\mathrm{Fe}$ in a dithionitecitrate system buffered with sodium bicarbonate (Ald and Fed) were extracted by the methods of Mehra and Jackson [37]. Concentrations of extracted $\mathrm{Fe}$ and $\mathrm{Al}$ were determined by sequential plasma spectrometry (Shimadzu, ICP-1000IV). Particle size distribution was determined using the pipette method. Clay mineral composition was identified by X-ray diffraction analysis using $\mathrm{CuK} \alpha$ radiation (Shimadzu, XD$\mathrm{D} 1 w)$. The point of zero salt effect (PZSE) was measured by the modified salt titration (STPT) method [38].

2.3. Data Analysis. Comparisons of mean soil properties and RLI between treatments were conducted by ANOVA with Bonferroni test. Comparison of seven species of seedlings performances between treatments was also conducted by ANOVA with Bonferroni's test. Mean seedling data values over 81 months were compared between treatments by repeated measures ANOVA with Scheffe's test. All dipterocarp species were included in the analysis of seedling data. The analyses were performed using the commercially available statistical package SPSS (ver. 11.5, Co., Tokyo).

\section{Results and Discussion}

3.1. Soil Physicochemical Properties, Soil Temperature, and Light Condition. The vertical distributions of general soil physicochemical properties and sesquioxide properties were similar among treatments (Figure 2). Aluminium (Ald) and iron (Fed) extracted by dithionite-citrate and aluminium extracted by ammonium oxalate (Alo) contents increased with depth and were correlated with clay content $(r=$ $0.875^{* *}, r=0.784^{* *}$, and $\left.r=0.798^{* *}\right)$. Fractions of Ald and Fed were translocated with clay downward in the soil [39]. On the contrary, both the iron extracted by ammonium oxalate (Feo) content and the Feo/Fed ratio decreased with depth. The low Feo/Fed value in the deepest horizon reflected strong weathering. Feo is known to reflect the amount of ferrihydrite and $\mathrm{Fe}$ included in organic complexes in the organic matter [39-41]. Representative clay mineral composition at the site was also similar among treatments. The soil contained chlorite, hydroxy-interlayered vermiculite, illite, kaolin minerals, lepidocroite, gibbsite, goethite, and quartz. Because kaolin minerals dominated and are a 1:1-type clay mineral, the soil 

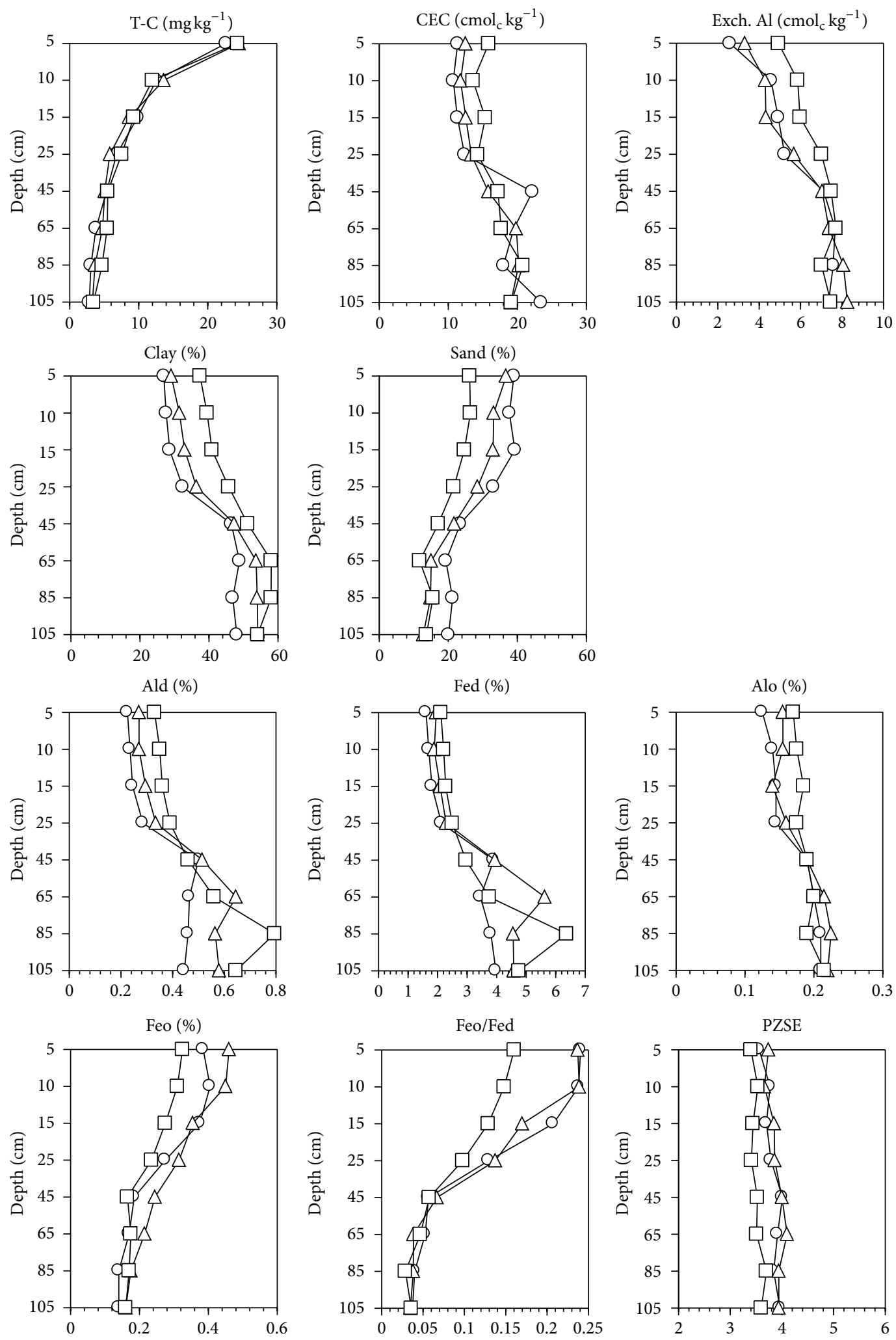

FIGURE 2: Vertical distribution of soil properties in the grassland, secondary forest, and logged forest in 2000; ○: grassland, $\triangle$ : secondary forest, $\square$ : logged forest. T-C: total carbon; CEC: cation exchange capacity; Exch. Al, exchangeable aluminium; Ald and Fed: Al and Fe contents extracted by dithionite-citrate; Alo and Feo: $\mathrm{Al}$ and Fe contents extracted by ammonium oxalate; PZSE: point of zero salt effect. 
TABLE 1: Differences in surface soil properties and relative light intensities in the grassland, secondary forest, and logged forest.

\begin{tabular}{|c|c|c|c|c|}
\hline & Grassland & Secondary forest & Logged forest & $n$ \\
\hline $\mathrm{pH}$ & $5.43(\mathrm{a})$ & $4.81(\mathrm{~b})$ & $4.83(\mathrm{~b})$ & 7 \\
\hline $\mathrm{EC}\left(\mathrm{mS} \mathrm{m}^{-1}\right)$ & $4.76(\mathrm{ab})$ & $3.83(\mathrm{a})$ & $5.22(\mathrm{~b})$ & 7 \\
\hline Exch. $\mathrm{Ca}\left(\mathrm{cmol}_{\mathrm{c}} \mathrm{kg}^{-1}\right)$ & $4.27(\mathrm{a})$ & $1.61(\mathrm{~b})$ & $2.09(\mathrm{~b})$ & 7 \\
\hline Exch. $\mathrm{K}\left(\mathrm{cmol}_{\mathrm{c}} \mathrm{kg}^{-1}\right)$ & $0.65(\mathrm{a})$ & $0.26(b)$ & $0.31(b)$ & 7 \\
\hline Exch. $\mathrm{Mg}\left(\mathrm{cmol}_{\mathrm{c}} \mathrm{kg}^{-1}\right)$ & $2.21(\mathrm{a})$ & $1.10(\mathrm{~b})$ & $1.55(\mathrm{ab})$ & 7 \\
\hline Exch. $\mathrm{Al}\left(\mathrm{cmol}_{\mathrm{c}} \mathrm{kg}^{-1}\right)$ & $1.07(\mathrm{a})$ & $3.59(b)$ & $3.11(\mathrm{ab})$ & 7 \\
\hline $\operatorname{CEC}\left(\mathrm{cmol}_{\mathrm{c}} \mathrm{kg}^{-1}\right)$ & $18.45(\mathrm{a})$ & $14.4(\mathrm{a})$ & 18.7 (a) & 7 \\
\hline $\mathrm{T}-\mathrm{C}\left(\mathrm{g} \mathrm{kg}^{-1}\right)$ & $34.8(\mathrm{ab})$ & 30.9 (a) & $40.4(\mathrm{~b})$ & 7 \\
\hline Penetrometer count $(0-10 \mathrm{~cm})$ & $3.46(a)$ & $2.59(\mathrm{~b})$ & $2.34(\mathrm{~b})$ & 56 \\
\hline Penetrometer count $(10-20 \mathrm{~cm})$ & $4.68(\mathrm{a})$ & $5.29(\mathrm{a})$ & $5.05(a)$ & 56 \\
\hline Relative light intensity (\%) & 79.7 (a) & 7.14 (b) & $4.00(\mathrm{~b})$ & 210 \\
\hline Maximum daily soil temperature $(5 \mathrm{~cm})\left({ }^{\circ} \mathrm{C}\right)$ & 34.3 (a) & $27.3(\mathrm{~b})$ & $25.2(\mathrm{c})$ & 30 \\
\hline Maximum daily soil temperature $(25 \mathrm{~cm})\left({ }^{\circ} \mathrm{C}\right)$ & 29.7 (a) & $25.6(\mathrm{~b})$ & $24.8(\mathrm{c})$ & 30 \\
\hline
\end{tabular}

EC: electric conductivity; Exch. Ca: exchangeable calcium; Exch. Mg: exchangeable magnesium; Exch. K: exchangeable potassium; Exch. Al: exchangeable aluminum; CEC: cation exchange capacity; T-C: total carbon. Values are means.

Different letters indicate significant differences by ANOVA with Bonferroni test $(P<0.05)$.

at the site could be considered as being in a weathered condition. However, the presence of a 2:1-type clay mineral (It), a 2:1:1-type clay mineral (Ch), and hydroxy-interlayered vermiculite (HIV) indicated that the soil had not yet reached a strongly weathered condition. The value of point of zero salt effects (PZSEs) was 3.5 to 3.8 and corresponded to typical values for tropical rain forests [42-44]. Based on these data, the soil at the planting site displayed favourable conditions for indigenous tree planting due to the relatively high levels of permanent negative charges derived from 2:1-type clay and an appropriate soil texture and inclination that prevents a substantial loss of soil nutrients by leaching. However, a high level of exchangeable $\mathrm{Al}$ was observed, especially in deeper soil layers, and may present a stress on planted seedlings [45].

Exchangeable bases were significantly higher in the surface horizon of the grassland than in the other treatments (Table 1), which was attributed to residual ash from shifting cultivation practices. This result is in agreement with the study of Ohta et al. [46]. On the other hand, exchangeable bases were lower in the secondary forest than in the other treatments. Following shifting cultivation, some pioneer trees, such as Macaranga, grew rapidly, and exchangeable bases may have been absorbed by the trees [30]. The amount of exchangeable $\mathrm{Al}$ showed an opposite tendency to that of exchangeable bases. The $\mathrm{pH}$ value reflected these results, being significantly higher in the grassland than in the other treatments.

Soil temperature at depths of 5 and $25 \mathrm{~cm}$ also differed significantly among treatments (Table 1). Soil temperatures at depths of 5 and $25 \mathrm{~cm}$ were the highest in the grassland, followed by secondary forest and logged forest, respectively. Daily maximum soil temperature at a depth of $5 \mathrm{~cm}$ reached $35-37^{\circ} \mathrm{C}$ in the grassland. At a depth of $5 \mathrm{~cm}$ in the grassland, there was a large difference in soil temperature between day and night compared with either that of other treatments or the temperatures at a $25 \mathrm{~cm}$ depth. This high surface soil temperature may cause increased root respiration and prevent water and nutrient absorption by fine roots in the grassland $[26,47,48]$. In contrast, maximum soil temperature in the secondary and logged forests did not exceed $27^{\circ} \mathrm{C}$ and had a small daily range. Similar tendencies in soil temperature were also reported between bare land and the understory of an Acacia plantation in Thailand [26].

The RLI was the highest in the grassland (approx. 79.7\%), followed by the secondary (8\%) and logged forests (5\%), respectively, because no trees were present in the grassland to provide shade (Table 1). There was no significant difference in RLI between the secondary and logged forests; however, the secondary forest showed a slightly higher light intensity than the logged forest.

3.2. Growth and Survival of Planted Dipterocarp Seedlings. The average values of height, diameter, and total biomass of all planted seedlings were significantly higher in the grassland than in the secondary or logged forests over 81 months (Figure 3). No significant differences were observed in these characteristics between secondary and logged forests. After 81 months, the mean tree heights of the seven species were 438,256 , and $198 \mathrm{~cm}$ in the grassland, secondary forest, and logged forest, respectively. Interspecific differences in the relative growth rate were also observed (Table 2). Seedlings of Shorea macrophylla, S. parvifolia, and S. virescens in the grassland treatment had a greater height and diameter growth rate, whereas those of S. ovata and Parashorea macrophylla displayed lower values. In the secondary forest, Dryobalanops beccarii and S. parvifolia had a relatively greater growth rate than the other species, although those of P. macrophylla and S. macrophylla were lower. In the logged forest, most species displayed a lower growth rate compared with grassland and secondary forests. Dryobalanops beccarii, S. ovata, and $S$. virescens displayed a higher growth rate compared with $P$. 
TABLE 2: Relative growth rate in height $\left(\mathrm{RGR}_{\text {height }}\right)$, in diameter $\left(\mathrm{RGR}_{\text {diameter }}\right)$, and percentage of survivors in relation to all planted individuals over 62 months of seven dipterocarp forest species.

\begin{tabular}{|c|c|c|c|c|c|c|c|c|c|}
\hline \multirow{2}{*}{ Species } & \multicolumn{3}{|c|}{$\mathrm{RGR}_{\text {height }}\left(\mathrm{cm} \mathrm{cm}^{-1}\right.$ year $\left.^{-1}\right)$} & \multicolumn{3}{|c|}{$\mathrm{RGR}_{\text {diameter }}\left(\mathrm{mm} \mathrm{mm}^{-1}\right.$ year $\left.^{-1}\right)$} & \multicolumn{3}{|c|}{ Survivor (\%) } \\
\hline & Grassland & $\begin{array}{l}\text { Secondary } \\
\text { forest }\end{array}$ & $\begin{array}{c}\text { Logged } \\
\text { forest }\end{array}$ & Grassland & $\begin{array}{l}\text { Secondary } \\
\text { forest }\end{array}$ & $\begin{array}{c}\text { Logged } \\
\text { forest }\end{array}$ & Grassland & $\begin{array}{l}\text { Secondary } \\
\text { forest }\end{array}$ & $\begin{array}{c}\text { Logged } \\
\text { forest }\end{array}$ \\
\hline Dryobalanops beccarii & $0.389(\mathrm{abc})$ & $0.316(a)$ & $0.248(\mathrm{ab})$ & $0.348(\mathrm{ab})$ & $0.328(\mathrm{a})$ & $0.231(\mathrm{a})$ & $11.1(\mathrm{bc})$ & $55.5(\mathrm{bc})$ & $49.9(\mathrm{ab})$ \\
\hline Parashorea macrophylla & $0.288(\mathrm{c})$ & $0.188(c)$ & $0.143(c)$ & $0.310(b)$ & $0.200(\mathrm{c})$ & $0.095(\mathrm{~d})$ & $15.5(\mathrm{bc})$ & $83.2(\mathrm{a})$ & $43.8(\mathrm{ab})$ \\
\hline Shorea macrophylla & $0.455(\mathrm{ab})$ & $0.105(\mathrm{~d})$ & $0.191(b c)$ & $0.448(\mathrm{a})$ & $0.124(\mathrm{~d})$ & $0.162(\mathrm{bc})$ & $5.2(\mathrm{bc})$ & $53.2(\mathrm{bc})$ & $62.8(\mathrm{a})$ \\
\hline S. ovata & $0.233(\mathrm{bc})$ & $0.275(\mathrm{ab})$ & $0.283(\mathrm{ab})$ & $0.254(\mathrm{~b})$ & $0.274(\mathrm{~b})$ & $0.185(\mathrm{ab})$ & $1.9(\mathrm{c})$ & $62.0(\mathrm{abc})$ & $11.5(\mathrm{c})$ \\
\hline S. parvifolia & $0.420(\mathrm{ab})$ & $0.328(a)$ & $0.220(\mathrm{ab})$ & $0.363(\mathrm{ab})$ & $0.308(\mathrm{ab})$ & $0.123(\mathrm{~cd})$ & $17.1(\mathrm{bc})$ & $40.7(\mathrm{c})$ & $27.1(\mathrm{bc})$ \\
\hline S. seminis & $0.351(\mathrm{bc})$ & $0.225(\mathrm{bc})$ & $0.186(\mathrm{bc})$ & $0.344(\mathrm{~b})$ & 0.277 (b) & $0.186(\mathrm{ab})$ & $46.3(\mathrm{a})$ & $61.5(\mathrm{abc})$ & $63.2(\mathrm{a})$ \\
\hline S. virescens & $0.458(\mathrm{a})$ & $0.207(\mathrm{bc})$ & $0.295(\mathrm{a})$ & $0.401(\mathrm{a})$ & $0.217(\mathrm{c})$ & $0.205(\mathrm{ab})$ & $25.4(\mathrm{ab})$ & $78.6(\mathrm{ab})$ & $53.2(\mathrm{ab})$ \\
\hline
\end{tabular}

Different letters indicate significant differences among species in each treatment by ANOVA with Bonferroni test $(P<0.001)$.

TABLE 3: Correlation between relative light intensity and seedlings survivor, relative growth rate in height $\left(\mathrm{RGR}_{\text {height }}\right)$ and diameter ( $\left.\mathrm{RGR}_{\text {diameter }}\right)$ among three treatments during 0-24 months and 24-81 months.

\begin{tabular}{|c|c|c|c|c|c|c|c|c|c|c|c|c|}
\hline \multirow{3}{*}{ Species } & \multicolumn{4}{|c|}{ Survivor } & \multicolumn{4}{|c|}{$\mathrm{RGR}_{\text {height }}$} & \multicolumn{4}{|c|}{$\mathrm{RGR}_{\text {diameter }}$} \\
\hline & \multicolumn{2}{|c|}{$0-24$ months } & \multicolumn{2}{|c|}{ 24-81 months } & \multicolumn{2}{|c|}{ 0-24 months } & \multicolumn{2}{|c|}{ 24-81 months } & \multicolumn{2}{|c|}{ 0-24 months } & \multicolumn{2}{|c|}{ 24-81 months } \\
\hline & $R^{2}$ & $P$ & $R^{2}$ & $P$ & $R^{2}$ & $P$ & $R^{2}$ & $P$ & $R^{2}$ & $P$ & $R^{2}$ & $P$ \\
\hline Dryobalanops beccarii & -0.40 & $* *$ & -0.51 & * & 0.66 & $* *$ & - & ns & - & ns & 0.75 & $* * *$ \\
\hline Parashorea macrophylla & -0.42 & $* *$ & -0.60 & $* *$ & 0.77 & $* * *$ & 0.53 & 0.05 & - & ns & 0.67 & $* *$ \\
\hline Shorea macrophylla & -0.85 & $* * *$ & -0.51 & $*$ & - & ns & - & ns & 0.84 & $* * *$ & 0.97 & $* * *$ \\
\hline S. ovata & -0.30 & * & -0.78 & $* * *$ & 0.69 & $* *$ & - & ns & - & ns & - & ns \\
\hline S. parvifolia & -0.31 & * & - & ns & 0.92 & $* * *$ & - & ns & 0.66 & $* *$ & - & ns \\
\hline S. seminis & -0.46 & $* *$ & -0.76 & $* * *$ & 0.86 & $* * *$ & - & ns & 0.47 & * & - & ns \\
\hline S. virescens & -0.43 & $* *$ & - & ns & 0.72 & $* * *$ & - & ns & 0.85 & $* * *$ & - & ns \\
\hline
\end{tabular}

Different letters indicate significant differences among species in each treatment by ANOVA with Bonferroni's test $\left({ }^{*} P<0.05,{ }^{* *} P<0.01,{ }^{* * *} P<0.001\right)$.

macrophylla and S. macrophylla. Tree height growth in the grassland was similar to that of other dipterocarp tree species planted in open areas in Borneo, such as S. macrophylla (461 cm after 72 months [49]), S. ovata $(450 \mathrm{~cm}$ after 60 months [50]), and 11 other dipterocarp species (320 to $580 \mathrm{~cm}$ after 60 months [51]). The height of seedlings in the secondary forest and logged forest was lower than the heights recorded in these studies. Mean diameters at 81 months also displayed similar trends with tree heights, being 69, 25, and $19 \mathrm{~mm}$ in the grassland, secondary forest, and logged forest, respectively (Figure 3).

Total above- and belowground biomasses of all planted seedlings after 81 months were also the highest in the grassland condition, being 5,530, 524, and $296 \mathrm{~kg} \mathrm{ha}^{-1}$ in the grassland, secondary forest, and logged forest, respectively (Figure 3). High light conditions (79.7\%) may enhance photosynthetic rates [4], accelerating the growth of dipterocarp seedlings in the grassland, even though many seedlings died in the grassland. In fact, many dipterocarp species show higher growth rates at relatively high light intensities, such as the highest growth rate observed at $87.5 \%$ in five dipterocarp species in Sabah [52] and at 30-50\% in four dipterocarp species on the Malay Peninsula [22]. In contrast, early biomass accumulation was markedly greater in naturally regenerated secondary forest trees than in planted dipterocarp trees in this study. For example, both above- and belowground biomass of the regenerated forest trees 84 months after degradation accumulated approximately ninefold more biomass $\left(49,000 \mathrm{~kg} \mathrm{ha}^{-1}\right)$ than the dipterocarp seedlings in the grassland [53]. However, biomass accumulation in the regenerated forest may saturate at $\sim 100,000 \mathrm{~kg} \mathrm{ha}^{-1}$ at an age of only 20 years $[53,54]$. Therefore, if we consider long-term biomass accumulation, rehabilitation planting using dipterocarp trees may enable storage of large quantities of carbon in the degraded forest, because nondisturbed dipterocarp forests usually accumulate aboveground biomass exceeding $350,000 \mathrm{~kg} \mathrm{ha}^{-1}[1,55]$.

A significantly smaller number of seedlings survived in the grassland than in the secondary or logged forests after 81 months (Figure 3). In the grassland, the number of seedlings that survived decreased substantially after the initial 24 months (25\%), with only $13 \%$ of seedlings surviving 81 months after planting. Less than $10 \%$ of seedlings were alive in S. macrophylla and S. ovata in the grassland 62 months after planting (Table 2). After 81 months, most seedlings of $S$. macrophylla and S. ovata had died in the grassland (Table 5). In contrast, $46.3 \%$ of the seedlings of S. seminis were alive in the grassland 62 months after planting, whereas more 
TABLE 4: Correlation between soil hardness (penetrometer counts at the depth of $0-20 \mathrm{~cm}$ ) and seedlings survivor, relative growth rate in height $\left(\mathrm{RGR}_{\text {height }}\right)$ and diameter $\left(\mathrm{RGR}_{\text {diameter }}\right)$ during $0-24$ months and $24-81$ months in the secondary forest and logged forest.

\begin{tabular}{|c|c|c|c|c|c|c|c|c|c|c|c|c|}
\hline \multirow{3}{*}{ Species } & \multicolumn{4}{|c|}{ Survivor } & \multicolumn{4}{|c|}{$\mathrm{RGR}_{\text {height }}$} & \multicolumn{4}{|c|}{$\mathrm{RGR}_{\text {diameter }}$} \\
\hline & \multicolumn{2}{|c|}{$0-24$ months } & \multicolumn{2}{|c|}{ 24-81 months } & \multicolumn{2}{|c|}{$0-24$ months } & \multicolumn{2}{|c|}{ 24-81 months } & \multicolumn{2}{|c|}{ 0-24 months } & \multicolumn{2}{|c|}{ 24-81 months } \\
\hline & $R^{2}$ & $P$ & $R^{2}$ & $P$ & $R^{2}$ & $P$ & $R^{2}$ & $P$ & $R^{2}$ & $P$ & $R^{2}$ & $P$ \\
\hline Dryobalanops beccarii & - & ns & - & ns & - & ns & - & ns & - & ns & - & ns \\
\hline Parashorea macrophylla & - & ns & - & ns & - & ns & - & ns & - & ns & - & ns \\
\hline Shorea macrophylla & - & ns & - & ns & - & ns & -0.61 & * & - & ns & - & ns \\
\hline S. ovata & -0.59 & * & - & ns & - & ns & - & ns & -0.83 & $* *$ & - & ns \\
\hline S. parvifolia & - & ns & - & ns & - & ns & - & ns & - & ns & - & ns \\
\hline S. seminis & - & ns & - & ns & - & ns & - & ns & - & ns & - & ns \\
\hline S. virescens & - & ns & - & ns & - & ns & - & ns & - & ns & - & ns \\
\hline
\end{tabular}

Different letters indicate significant differences among species in each treatment by ANOVA with Bonferroni's test $\left({ }^{*} P<0.05,{ }^{* *} P<0.01\right)$.

TABLE 5: Seedlings height $(\mathrm{cm})$, diameter $(\mathrm{mm})$, and percentage of survivors (\%) in relation to all planted individuals at 81 months of seven dipterocarp forest species.

\begin{tabular}{|c|c|c|c|c|c|c|c|c|c|}
\hline \multirow{2}{*}{ Species } & \multicolumn{3}{|c|}{ Height $(\mathrm{cm})$} & \multicolumn{3}{|c|}{ Diameter $(\mathrm{mm})$} & \multicolumn{3}{|c|}{ Survivor (\%) } \\
\hline & Grassland & $\begin{array}{c}\text { Secondary } \\
\text { forest }\end{array}$ & $\begin{array}{c}\text { Logged } \\
\text { forest }\end{array}$ & Grassland & $\begin{array}{c}\text { Secondary } \\
\text { forest }\end{array}$ & $\begin{array}{c}\text { Logged } \\
\text { forest }\end{array}$ & Grassland & $\begin{array}{l}\text { Secondary } \\
\text { forest }\end{array}$ & $\begin{array}{c}\text { Logged } \\
\text { forest }\end{array}$ \\
\hline Dryobalanops beccarii & 438.3 (ns) & 370.4 (a) & 335.7 (a) & $54.0(\mathrm{~ns})$ & $26.8(\mathrm{ab})$ & 26.4 (a) & $6.6(\mathrm{~b})$ & $45.4(\mathrm{ab})$ & $45.2(\mathrm{ab})$ \\
\hline Parashorea macrophylla & $356.1(\mathrm{~ns})$ & $169.4(\mathrm{~b})$ & $81.7(\mathrm{~d})$ & $56.6(\mathrm{~ns})$ & 30.2 (a) & $11.9(\mathrm{~d})$ & $13.7(b)$ & 70.7 (a) & $36.5(\mathrm{ab})$ \\
\hline Shorea macrophylla & $557.5^{* \dagger}(-)$ & $160.4(b)$ & $178.9(\mathrm{bc})$ & $83.0^{* \dagger}(-)$ & $21.2(\mathrm{bc})$ & $22.8(\mathrm{ab})$ & $0.0(\mathrm{~b})$ & $43.9(\mathrm{ab})$ & $52.3(\mathrm{a})$ \\
\hline S. ovata & $232.0^{\dagger}(-)$ & $272.0(\mathrm{a})$ & $261.6(a b)$ & $24.7^{\dagger}(-)$ & $20.0(\mathrm{c})$ & $16.8(\mathrm{bcd})$ & $0.6(b)$ & $50.9(\mathrm{a})$ & $9.1(\mathrm{~b})$ \\
\hline S. parvifolia & 440.7 (ns) & $350.8(\mathrm{a})$ & $111.5(\mathrm{~cd})$ & 71.7 (ns) & $26.7(\mathrm{abc})$ & $11.4(\mathrm{~cd})$ & $18.5(\mathrm{ab})$ & $25.7(b)$ & $11.8(\mathrm{~b})$ \\
\hline S. seminis & 414.3 (ns) & 204.5 (b) & $143.3(\mathrm{~cd})$ & 47.2 (ns) & $21.4(\mathrm{bc})$ & $17.5(\mathrm{c})$ & 39.5 (a) & $51.1(\mathrm{ab})$ & $54.6(\mathrm{a})$ \\
\hline S. virescens & $383.4(\mathrm{~ns})$ & $195.8(\mathrm{~b})$ & $234.2(\mathrm{~b})$ & 61.7 (ns) & $20.8(\mathrm{c})$ & $24.0(\mathrm{ab})$ & $10.3(\mathrm{~b})$ & $63.9(\mathrm{a})$ & $40.9(\mathrm{ab})$ \\
\hline
\end{tabular}

${ }^{*}$ Data at 62 months after planting. ${ }^{\dagger}$ We exclude from statistical test due to less than three individuals remained.

Different letters indicate significant differences among species in each treatment by ANOVA with Bonferroni's test $(P<0.001)$.

than $60 \%$ of S. seminis seedlings were alive in secondary and logged forests. These values were in the range of other planting trials in open land. For example, 5.9\%-77.9\% of seedlings of 10 dipterocarp species survived for 2 years on an abandoned shifting-cultivation area in Kalimantan [56] and less than $20 \%$ of seedlings of several dipterocarps, remained after 2 years in degraded Imperata grassland [57]. In contrast, the number of seedlings surviving in secondary and logged forests, respectively, decreased from $73 \%$ and $60 \%$ after 24 months to $56 \%$ and $36 \%$ by 81 months after planting (Figure 3). More than $60 \%$ of $P$. macrophylla and S. virescens seedlings remained 81 months after planting in the secondary forest, while approximately $70 \%-90 \%$ of seedlings of $S$. parvifolia and S. ovata had died in the logged forest (Table 5). Higher survivability is usually reported in seedlings planted under secondary and/or logged forests; for example, 37.5\%$70.0 \%$ of S. parvifolia seedlings were alive after 24 months in Indonesian secondary forests where line planting methods have been used [27], and more than $94 \%$ of Dryobalanops aromatica and S. parvifolia seedlings also survived after 22 months in a secondary forest in Sarawak [58]. However, the high survivability in $S$. parvifolia recorded in previous studies may have subsequently declined after more than 2 years after planting, because our long-term monitoring revealed that only $11.8 \%$ and $25.7 \%$ of the seedlings remained 81 months after planting in the secondary and logged forests, respectively (Table 5).

3.3. Environmental Effects on Seedling Growth and Survival. In the grassland, the high light irradiance may reduce the survivability of dipterocarp seedlings. Correlation analysis for most species also showed that light intensity reduced the seedling survivability both over 0-24 months and 2481 months except for $S$. parvifolia and $S$. virescens over the 24- to 81-month period (Table 3 ). Conversely, the seedlings survived in the secondary forest and logged forest, except for S. ovata in logged forest (Table 4). Forest cover provided by some pioneer trees such as Macaranga species reduced the severe stress of strong sunlight and high soil temperature on the seedlings [28]. As a result, many seedlings may survive under the forested treatments. In contrast, light intensity also enhanced height and/or diameter growth for most species, especially height growth during the 0 - to 24-month period after planting (Table 3). Light intensity enhanced the diameter growth of S. macrophylla, S. parvifolia, and S. seminis 


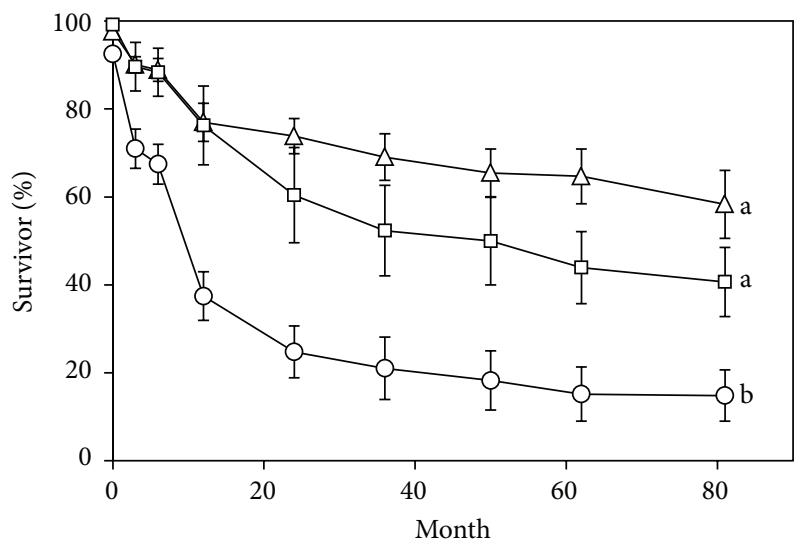

(a)

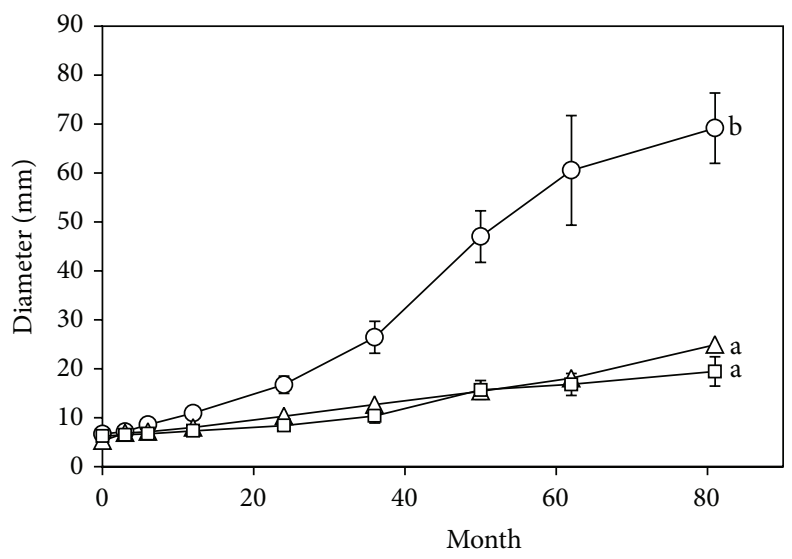

(c)

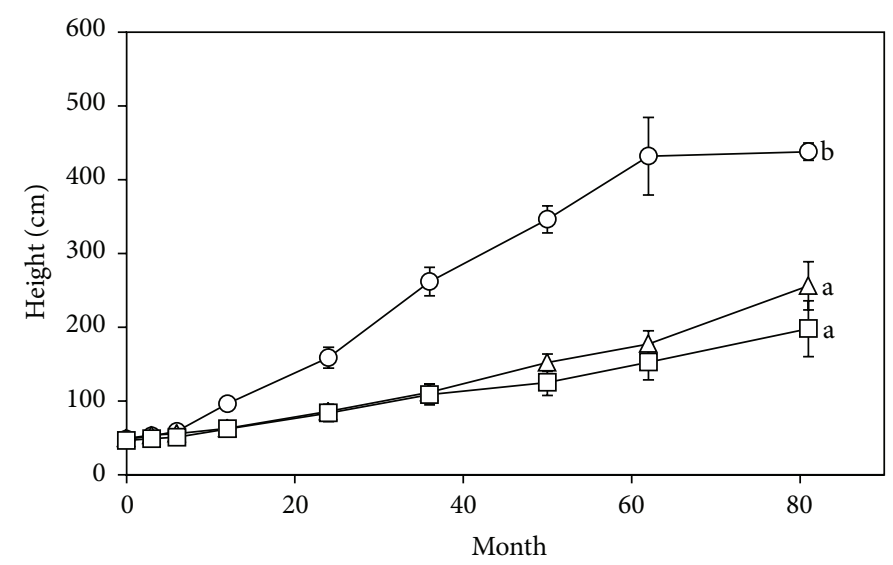

(b)

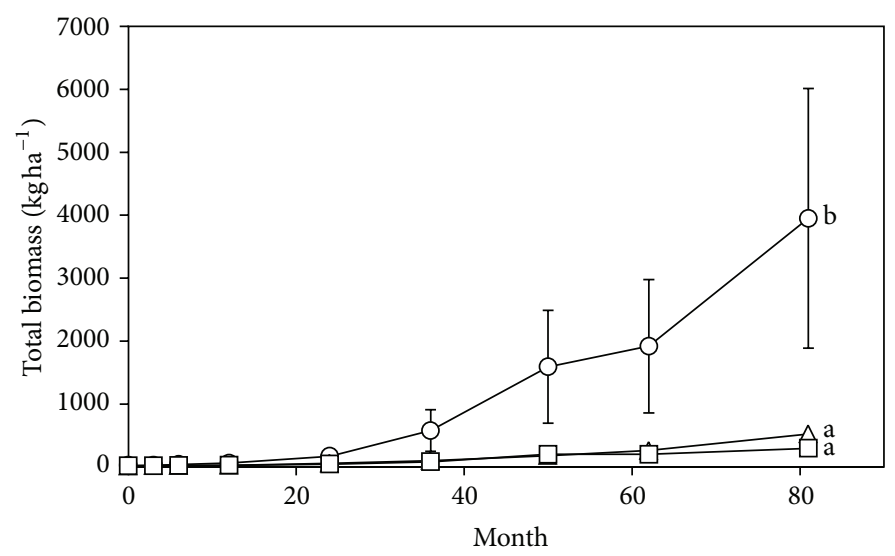

(d)

FIGURE 3: Percentage of survivor $(\%)$, height $(\mathrm{cm})$, diameter $(\mathrm{mm})$, and total biomass $\left(\mathrm{kg} \mathrm{ha}^{-1}\right)$ of seedlings after planting. Different letters indicate significant differences by repeated measures ANOVA with Scheffe's test over 81 months; $\circ$ : grassland, $\triangle$ : secondary forest, and $\square$ : logged forest. $P<0.001$ for treatment and time effects (repeated measures ANOVA).

during the initial 24 months after planting and the diameter growth of D. beccarii, P. macrophylla, and S. macrophylla during the 24- to 81-month period after planting.

In contrast, a close correlation between the pooled survivor data and penetrometer counts at a depth of 10$20 \mathrm{~cm}$ (soil hardness) was identified during the early growing stage (0-24 months) in the forested area $(r=-0.693$, $P<$ 0.01: data not shown). Very hard soil conditions were found in some parts of the study area, which was attributable to anthropogenic activities including compaction from selective logging accompanied by heavy traction. This compacted soil layer may prevent the elongation of seedling roots from the planting hole to the adjacent soil and may therefore suppress seedling survival during the early growing stage. Several studies have reported similar negative effects of soil compaction in terms of survival and growth rates of dipterocarp seedlings $[59,60]$. However, correlation analysis for each species indicated that soil hardness at a depth of 0 $20 \mathrm{~cm}$ reduced survivability and the diameter growth rate of only $S$. ovata during the 0 - to 24 -month period and limited the height growth rate of $S$. macrophylla during the 24- to 81-month period (Table 4). This relatively limited effect on soil hardness compared with the pooled analysis of all species may be due to the limited number of samples available for the analysis of each species. Further studies on the effect of soil hardness for planted dipterocarp seedlings are needed to develop suitable rehabilitation techniques for degraded tropical rain forest in Southeast Asia.

3.4. Summary of Species Traits in the Three Vegetation Types. We summarized the responses of all seven species in the three treatments and recommended suitable planting conditions. Dryobalanops beccarii displayed the highest diameter growth rate among the species in the secondary and logged forests, and more than $45 \%$ of seedlings survived in these locations (Tables 2 and 5). More than $93 \%$ of seedlings died in the grassland treatment, which indicates that this species is more suitable for planting in secondary or logged forests. Parashorea macrophylla in the secondary forest displayed the highest diameter growth and survivability of all species investigated. In contrast, the height and diameter growth rate in the logged forest were substantially lower than in the other species and treatments (Table 2). Based on these 
results, $P$. macrophylla is considered to be suitable for planting in secondary forests. Shorea macrophylla planted in the grassland displayed the highest growth rate and reached more than $5.5 \mathrm{~m}$ in height at 62 months (Tables 2 and 5). However, most seedlings had died after 81 months. Relatively low drought tolerance in this species may be responsible for this low survival in grassland [4]. In our observation, seedlings planted near the stream were still alive in the grassland even after 81 months, indicating that this species may be suitable for planting in grassland locations with high soil moisture conditions. In contrast, more than $43 \%$ of seedlings survived in secondary and logged forests after 81 months. After 81 months, less than $10 \%$ of $S$. ovata seedlings were alive in grassland and logged forest, but half of them survived in the secondary forest (Tables 2 and 5). The height growth rate in the secondary forest was also the greatest of all species. Thus, S. ovata should be planted in secondary forest. Shorea parvifolia displayed the highest height growth rate in the grassland and secondary forest of all species investigated, whereas the growth rate and survivability in the logged forest were relatively low. Leaf drought tolerance was also higher compared with the other planted species [4]. Thus, this species may be suitable for planting under relatively bright conditions. Approximately $40 \%$ of S. seminis seedlings survived in the grassland after 81 months (Table 5). This indicates that the species can be planted under grassland conditions, although more than $50 \%$ of seedlings were also alive in the secondary and logged forests. The growth rate of $S$. virescens in the grassland was relatively high compared with other species, although about $90 \%$ of seedlings eventually died (Tables 2 and 5). This species may be suitable for planting in secondary and logged forests due to their relatively higher survivability in these treatments and their moderate growth rates.

\section{Conclusions}

Nutrient content is closely related to clay content and clay mineral compositions. Therefore, the latter two factors can be used to evaluate soil fertility. The survival of planted dipterocarp seedlings was significantly limited by the high light intensity, especially for D. beccarii, S. macrophylla, and S. ovata in the grassland. However, light intensity also enhanced height and/or diameter growth rate for all seven dipterocarp species. The survival and/or growth of S. macrophylla and $S$. ovata were limited by the hard soil conditions in both secondary and logged forests. A more detailed analysis of the relationships between the growth of planted dipterocarp seedlings, local vegetation conditions, and soil factors is required for the further development of rehabilitation techniques in tropical rain forests.

\section{Acknowledgments}

The authors thank the Forest Department Sarawak for their assistance in our study. This work was partly supported by a Grant-in-Aid for Scientific Research (09NP0901, 13575038, and 17405031), the Nissay Foundation, and the Sasakawa Scientific Research grant from the Japan Science Society.

\section{References}

[1] T. C. Whitmore, An Introduction to Tropical Rain Forests, Oxford University Press, Oxford, UK, 1998.

[2] L. M. Curran, S. N. Trigg, A. K. McDonald et al., "Lowland forest loss in protected areas of indonesian borneo," Science, vol. 303, no. 5660, pp. 1000-1003, 2004.

[3] S. J. Wright, "Tropical forests in a changing environment," Trends in Ecology and Evolution, vol. 20, no. 10, pp. 553-560, 2005.

[4] T. Kenzo, T. Ichie, T. Ozawa et al., "Leaf physiological and morphological responses of seven dipterocarp seedlings to degraded forest environments in Sarawak, Malaysia: a case study of forest rehabilitation practice," Tropics, vol. 17, no. 1, pp. $1-16,2007$.

[5] S. Appanah and G. Weinland, "Planting quality timber trees in peninsular Malaysia. A review," Malayan Foresters Records 38, FRIM, Kuala Lumpur, Malaysia, 1993.

[6] C. J. Kettle, "Ecological considerations for using dipterocarps for restoration of lowland rainforest in Southeast Asia," Biodiversity and Conservation, vol. 19, no. 4, pp. 1137-1151, 2010.

[7] D. Lamb, P. D. Erskine, and J. A. Parrotta, "Restoration of degraded tropical forest landscapes," Science, vol. 310, no. 5754, pp. 1628-1632, 2005.

[8] R. F. Fisher, "Amelioration of degraded rain forest soils by plantations of native trees," Soil Science Society of America Journal, vol. 59, no. 2, pp. 544-549, 1995.

[9] J. Castro, R. Zamora, J. A. Hódar, and J. M. Gómez, "Use of shrubs as nurse plants: a new technique for reforestation in Mediterranean Mountains," Restoration Ecology, vol. 10, no. 2, pp. 297-305, 2002.

[10] S. Elliott, P. Navakitbumrung, C. Kuarak, S. Zangkum, V. Anusarnsunthorn, and D. Blakesley, "Selecting framework tree species for restoring seasonally dry tropical forests in northern Thailand based on field performance," Forest Ecology and Management, vol. 184, no. 1-3, pp. 177-191, 2003.

[11] M. Kitao, R. Yoneda, H. Tobita et al., "Susceptibility to photoinhibition in seedlings of six tropical fruit tree species native to Malaysia following transplantation to a degraded land," Trees, vol. 20, no. 5, pp. 601-610, 2006.

[12] T. Kenzo, R. Yoneda, Y. Matsumoto, M. A. Azani, and N. M. Majid, "Leaf photosynthetic and growth responses on four tropical tree species to different light conditions in degraded tropical secondary forest, Peninsular Malaysia," Japan Agricultural Research Quarterly, vol. 42, no. 4, pp. 299-306, 2008.

[13] D. Lamb, Regreening the Bare Hills, Springer, Business Media, New York, NY, USA, 2011.

[14] I. C. Baillie, P. S. Ashton, M. N. Court, J. A. R. Anderson, E. A. Fitzpatrick, and J. Tinsley, "Site characteristics and the distribution of tree species in mixed dipterocarp forest on tertiary sediments in central sarawak, Malaysia," Journal of Tropical Ecology, vol. 3, no. 3, pp. 201-220, 1987.

[15] S. J. Davies, P. A. Palmiotto, P. S. Ashton, H. S. Lee, and J. V. Lafrankie, "Comparative ecology of 11 sympatric species of Macaranga in Borneo: tree distribution in relation to horizontal and vertical resource heterogeneity," Journal of Ecology, vol. 86, no. 4, pp. 662-673, 1998. 
[16] S. J. Davies, "Tree mortality and growth in 11 sympatric Macaranga species in Borneo," Ecology, vol. 82, no. 4, pp. 920 932, 2001.

[17] P. A. Palmiotto, S. J. Davies, K. A. Vogt, M. S. Ashton, D. J. Vogt, and P. S. Ashton, "Soil-related habitat specialization in dipterocarp rain forest tree species in Borneo," Journal of Ecology, vol. 92, no. 4, pp. 609-623, 2004.

[18] T. Kenzo, T. Ichie, Y. Watanabe, R. Yoneda, I. Ninomiya, and T. Koike, "Changes in photosynthesis and leaf characteristics with tree height in five dipterocarp species in a tropical rain forest," Tree Physiology, vol. 26, no. 7, pp. 865-873, 2006.

[19] J. Evans, "Introduction," in Plantation Forestry in the Tropics, pp. 3-11, Oxford University Press, New York, NY, USA, 1996.

[20] D. Hattori, T. Kenzo, N. Yamauchi et al., "Effects of environmental factors on growth and mortality of Parashorea macrophylla (Dipterocarpaceae) planted on slopes and valleys in a degraded tropical secondary forest in Sarawak, Malaysia," Soil Science and Plant Nutrition, vol. 59, pp. 218-228, 2013.

[21] P. S. Ashton, "Dipterocarpaceae," in Flora Malesiana. Series 1: Spermatophyta, vol. 9 of Systematic Revisions, pp. 237-552, Martinus Nijhoff Publishers, Dordrecht, Netherlands, 1982.

[22] S. Sasaki and T. Mori, "Growth responses of dipterocarp seedlings to light," Malaysian Forester, vol. 44, pp. 319-345, 1981.

[23] C. F. Symington, "Foresters' manual of dipterocarps," Malayan Foresters Records 16, Forest Research Institute Malaysia, Kuala Lumpur, Malaysia, 2004.

[24] P. M. S. Ashton, S. Gamage, I. A. U. N. Gunatilleke, and C. V. S. Gunatilleke, "Restoration of a Sri Lankan rainforest: using Carribean pine Pinus caribaea as a nurse for establishing latesuccessional tree species," Journal of Applied Ecology, vol. 34, no. 4, pp. 915-925, 1997.

[25] R. Otsamo, "Effect of nurse tree species on early growth of Anisoptera marginata Korth. (Dipterocarpaceae) on an Imperata cylindrica (L.) Beauv. grassland site in South Kalimantan, Indonesia," Forest Ecology and Management, vol. 105, no. 1-3, pp. 303-311, 1998.

[26] M. Norisada, G. Hitsuma, K. Kuroda et al., “Acacia mangium, a nurse tree candidate for reforestation on degraded sandy soils in the Malay Peninsula," Forest Science, vol. 51, no. 5, pp. 498-510, 2005.

[27] G. Ådjers, S. Hadengganan, J. Kuusipalo, K. Nuryanto, and L. Vesa, "Enrichment planting of dipterocarps in logged-over secondary forests: effect of width, direction and maintenance method of planting line on selected Shorea species," Forest Ecology and Management, vol. 73, no. 1-3, pp. 259-270, 1995.

[28] T. Kenzo, R. Yoneda, Y. Matsumoto, A. M. Azani, and M. N. Majid, "Growth and photosynthetic response of four Malaysian indigenous tree species under different light conditions," Journal of Tropical Forest Science, vol. 23, no. 3, pp. 271-281, 2011.

[29] I. Ninomiya, K. Sakurai, K. Harada, J. J. Kendawang, H. S. Lee, and K. Ogino, "Island and corridor planting system in ecosystem rehabilitation," in Proceedings of the Workshop on Forest Ecosystem Rehabilitation Kuching, Sarawak, Malaysia, pp. 18-21, Forest Department Sarawak, Kuching, Malaysia, November 1999.

[30] D. Hattori, T. Kenzo, J. J. Kendawang et al., "Effects of light intensity and soil physico-chemical properties on seedling mortality and growth of six dipterocarp species planted for rehabilitation of degraded grassland, secondary forest and logged forest in Sarawak, Malaysia," Japanese Journal of Forest Environment, vol. 51, pp. 105-115, 2009.
[31] E. Salati, T. E. Lovejoy, and P. B. Vose, "Precipitation and water recycling in tropical rain forests with special reference to the amazon basim," The Environmentalist, vol. 3, no. 1, pp. 67-72, 1983.

[32] Agriculture Consultancy, Semi-Detailed Soil Survey of Niah Agroforestory Area, KTA Agriculture Consultancy Sdn Bhd, Kuching, Malaysia, 1993.

[33] I. C. Baillie, "Report on a detailed examination of soils of silvicultural research plot 53," Niah Forest Reserve, Forest Department Sarawak, Soil Survey Research Section, Kuching, Malaysia, 1972.

[34] Soil Survey Staff, Keys to Soil Taxonomy, Pocahontas Press, Blacksburg, Va, USA, 1999.

[35] T. Kenzo, Studies on ecophysiological properties related to photosynthesis of Dipterocarpaceae in tropical rainforest of Sarawak [Ph.D. thesis], Ehime University, Matsuyama, Japan, 2004.

[36] J. A. Mckeague and J. H. Day, "Dithionite- and oxalateextractable $\mathrm{Fe}$ and $\mathrm{Al}$ as aids in differentiating various classes of soils," Journal of Soil Science, vol. 46, pp. 13-22, 1966.

[37] O. P. Mehra and M. L. Jackson, "Iron oxide removal from soils and clays by a dithionite-citrate system buffered with sodium bicarbonate," Clays and Clay Minerals, vol. 7, pp. 317-327, 1960.

[38] K. Sakurai, Y. Ohdate, and K. Kyuma, "Comparison of salt titration and potentiometric titration method for the determination of zero point charge (ZPC)," Soil Science and Plant Nutrition, vol. 34, pp. 171-182, 1988.

[39] S. Ohta, S. Effendi, N. Tanaka, and S. Miura, "Ultisols of lowland dipterocarp forest in east Kalimantan, Indonesia. III clay minerals, free oxides, and exchangeable cations," Soil Science and Plant Nutrition, vol. 39, pp. 1-12, 1993.

[40] A. S. Campbell and U. Schwertmann, "Iron oxide mineralogy of placic horizons," Journal of Soil Science, vol. 35, no. 4, pp. 569$582,1984$.

[41] O. K. Borggaard, "Phase identification by selective dissolution techniques," in Iron in Soils and Clay Minerals, J. W. Stucki, B. A. Goodman, U. Schwertmann, and D. Reildel, Eds., pp. 83-98, Publishing Company, Dordrecht, Netherlands, 1988.

[42] K. Sakurai, "Changes in zero point of charge (ZPC) in the weathering process of soil material," Pedologist, vol. 34, pp. 214, 1990 (Japanese).

[43] S. Ishizuka, S. Tanaka, K. Sakurai et al., "Characterization and distribution of soils at Lambir Hills National Park in Sarawak, Malaysia, with special reference to soil hardness and soil texture," Tropics, vol. 8, pp. 31-44, 1998.

[44] S. Ishizuka, K. Sakurai, J. J. Kendawang, and H. S. Lee, "Soil characteristics of an abandoned shifting cultivation land in Sarawak, Malaysia," Tropics, vol. 10, pp. 251-263, 2000.

[45] K. Tahara, M. Norisada, T. Hogetsu, and K. Kojima, "Aluminum tolerance and aluminum-induced deposition of callose and lignin in the root tips of Melaleuca and Eucalyptus species," Journal of Forest Research, vol. 10, no. 4, pp. 325-333, 2005.

[46] S. Ohta, K. Morisada, N. Tanaka, Y. Kiyono, and S. Effendi, "Are soils in degraded dipterocarp forest ecosystems deteriorated? A comparison of Imperata grasslands, degraded secondary forests, and primary forests," in Rainforest Ecosystems of East Kalimantan: El Niño, Drought, Fire and Human Impacts, E. Guhardja, M. Fatawi, M. Sutisna, T. Mori, and S. Ohta, Eds., pp. 49-58, Springer, Tokyo, Japan, 2000.

[47] W. Larcher, Physiological Plant Ecology, Springer, New York, NY, USA, 2003. 
[48] P. Gregory, "Plant root," in Growth, Activity and Interaction with Soils, p. 318, Blackwell Publishing, Oxford, UK, 2006.

[49] S. E. Lee, A. Itoh, M. Kanzaki, and T. Yamakura, "Height growth of Engkabang Jantong, Shorea macrophylla (De Vr.) Ashton, in a plantation forest in Sarawak," Tropics, vol. 7, no. 1/2, pp. 67-80, 1997.

[50] M. A. Alias, M. Z. Hamzah, K. Fujiwara, and S. Meguro, "Rehabilitation of tropical rainforests based on potential natural vegetation species for degraded areas in Sarawak, Malaysia," Tropics, vol. 7, no. 3/4, pp. 223-239, 1998.

[51] S.-I. Meguro and A. Miyawaki, "A study of initial growth behaviour of planted Dipterocarpaceae trees for restoration of tropical rain forests in Borneo/Malaysia," Tropical Ecology, vol. 38, no. 2, pp. 237-245, 1997.

[52] D. I. Nicholson, "Light requirements of seedlings of five species of Dipterocarpaceae," Malaysian Forester, vol. 23, pp. 344-356, 1960.

[53] T. Kenzo, T. Ichie, D. Hattori, J. J. Kendawang, K. Sakurai, and I. Ninomiya, "Changes in above- and belowground biomass in early successional tropical secondary forests after shifting cultivation in Sarawak, Malaysia," Forest Ecology and Management, vol. 260, no. 5, pp. 875-882, 2010.

[54] S. Brown and A. E. Lugo, "Tropical secondary forests," Journal of Tropical Ecology, vol. 6, no. 1, pp. 1-32, 1990.

[55] T. Kira and T. Shidei, "Primary production and turnover of organic matter in different forest ecosystems of the western Pacific," Japanese Journal of Ecology, vol. 17, pp. 70-87, 1967.

[56] G. Ådjers, J. Kuusipalo, S. Hadengganan, K. Nuryanto, and L. Vesa, "Performance of ten dipterocarp species in restocking logged-over forest areas subjected to shifting cultivation," Journal of Tropical Forest Science, vol. 9, no. 2, pp. 151-160, 1996.

[57] A. Otsamo, G. Ådjers, T. S. Hadi, J. Kuusipalo, and R. Vuokko, "Evaluation of reforestation potential of 83 tree species planted on Imperata cylindrica dominated grassland: a case study from South Kalimantan, Indonesia," New Forests, vol. 14, no. 2, pp. 127-143, 1997.

[58] A. Vincent and S. J. Davies, "Effects of nutrient addition, mulching and planting-hole size on early performance of Dryobalanops aromatica and Shorea parvifolia planted in secondary forest in Sarawak, Malaysia," Forest Ecology and Management, vol. 180, no. 1-3, pp. 261-271, 2003.

[59] R. Nussbaum, J. Anderson, and T. Spencer, "Factors limiting the growth of indigenous tree seedlings planted on degraded rainforest soils in Sabah, Malaysia," Forest Ecology and Management, vol. 74, no. 1-3, pp. 149-159, 1995.

[60] M. A. Pinard, M. G. Barker, and J. Tay, "Soil disturbance and post-logging forest recovery on bulldozer paths in Sabah, Malaysia," Forest Ecology and Management, vol. 130, no. 1-3, pp. 213-225, 2000. 

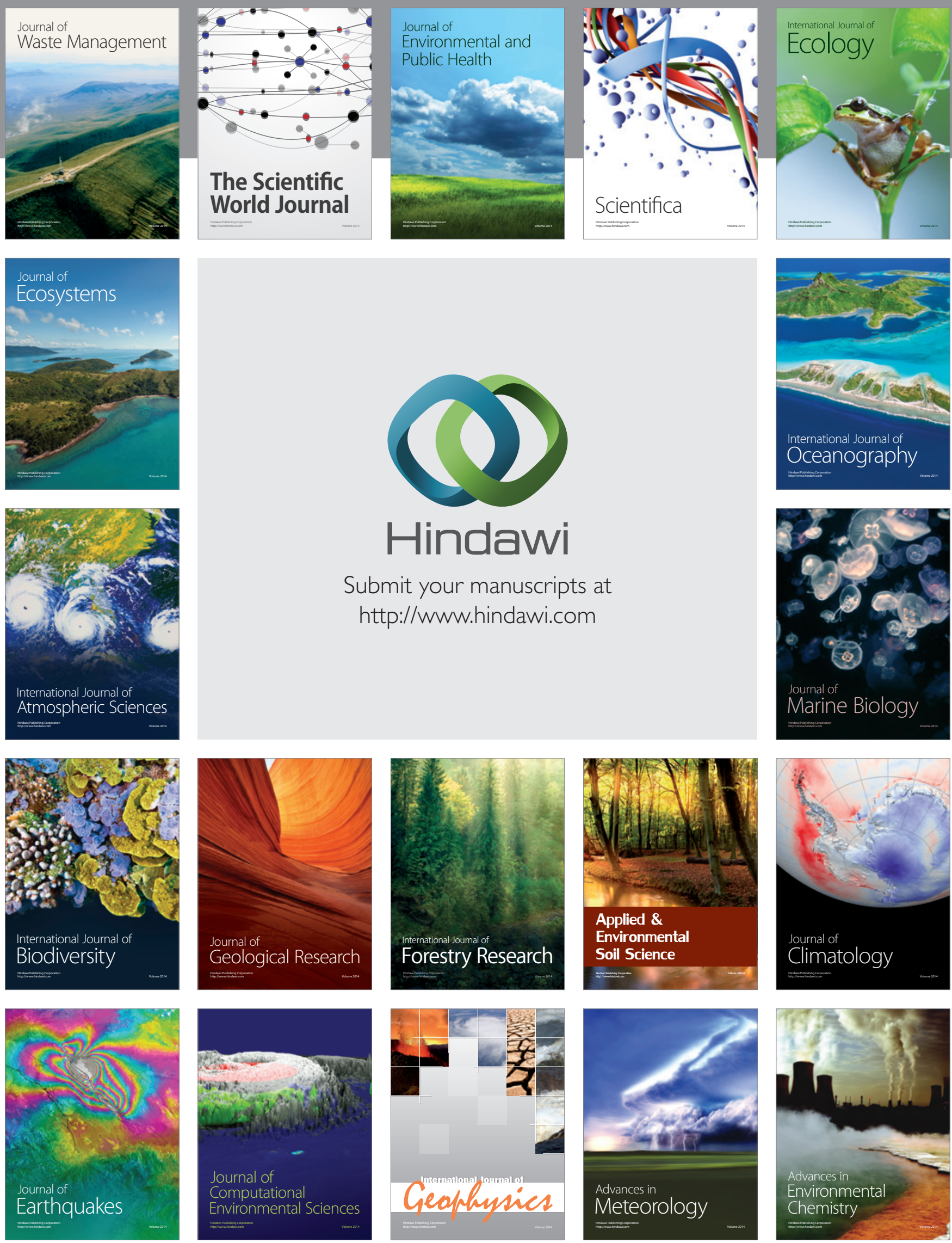